\title{
Bis 4,5-diazafluoren-9-one silver(I) nitrate: synthesis, X-ray structures, solution chemistry, hydrogel loading, DNA coupling and anti-bacterial screening
}

\author{
Alshima'a A. Massoud $*^{*}$, Yousry M. Gohar ${ }^{*}$, Vratislav Langer $^{a}$, Per Lincoln ${ }^{a}$, Frida R. Svensson $^{a}$, \\ Janne Jänis ${ }^{c}$, Sofie T. Gårdebjer ${ }^{\text {a,d }}$, Matti Haukka ${ }^{c}$, Fabian Jonsson ${ }^{a}$, Emma Aneheim ${ }^{a}$, Peter
} Löwenhielm ${ }^{\mathrm{d}}$, Morsy A. M. Abu-Youssef ${ }^{e}$ and Lars R. Öhrström*a,

\footnotetext{
${ }^{a}$ Dept. of Chemical and Biological Engineering, Chalmers University of Technology, SE-412 96 Gothenburg, Sweden. E-mail:shimo@chalmers.se; langer@chalmers.se; ohrstrom@chalmers.se; gardebje@student.chalmers.se

${ }^{\mathrm{b}}$ Dept. of Microbiology, University of Alexandria, P.O. Box 426 Ibrahimia, 21321 Alexandria, Egypt; E-mail: ymgohar@yahoo.com

${ }^{c}$ Dept. of Chemistry, University of Eastern Finland, P.O.Box 111, FI-80101, Joensuu, Finland, E-mail: matti.haukka@joensuu.fi,janne.janis@uef.fi

${ }^{d}$ Mölnlycke Health Care AB, Box 13080 SE-402 52 Gothenburg, Sweden, Peter.Lowenhielm@molnlycke.com

${ }^{\mathrm{e}}$ Dept. of Chemistry, University of Alexandria, P.O. Box 426 Ibrahimia, 21321 Alexandria, Egypt; E-mail: morsy5@hotmail.com
}

\begin{abstract}
Synthesis of bis-4,5-diazafluoren-9-one silver(I) nitrate $\mathbf{I}$, (dafone $=4,5$-diazafluoren-9-one) and low temperature X-ray single crystal structure of $\left[\mathrm{Ag}(4,5 \text {-diazafluoren-9-one })_{2} \mathrm{NO}_{3}\right]$, crystal form $\mathbf{1}$, and a re-determination of $\left[\mathrm{Ag}(4,5 \text {-diazafluoren-9-one })_{2}\right] \mathrm{NO}_{3} \cdot \mathrm{H}_{2} \mathrm{O}$, crystal form 2 are presented. Crystal form 1 has a distorted trigonal planar coordination geometry around $\mathrm{Ag}(\mathrm{I})$ with an N-Ag-N bond angle of $123.45(7)^{\circ}$. Crystal form 2 has a perfect linear coordination around Ag, with N-Ag$\mathrm{N} 180.0^{\circ}$. Compound I was characterized by ${ }^{1} \mathrm{H}-\mathrm{NMR}$, biological activity and ESI-MS in DMSO at room temperature. The biological activity was determined against 6 different resistant clinical isolates; two Gram-positive (Staphylococcus aureus and Streptococcus pyogenes) and four Gramnegative (Pseudomonas aeruginosa, Klebsiella pneumoniae, Proteus mirabilis, and Salmonella sp.) in comparison with 15 known antibiotics used in the treatment of diabetic foot infections. Compound I showed broad spectrum activity against all the test organisms. Proteus mirabilis, Staphylococcus aureus and Proteus mirabilis were the most sensitive clinical isolates (MIC = 4, 6 and $4 \mu \mathrm{g} / \mathrm{ml}$, respectively). Three different hydrogels containing $\mathbf{I}$ or $\mathrm{Ag}_{2} \mathrm{SO}_{4}$ were prepared and the antimicrobial activity against Pseudomonas aeruginosa (ATCC 15442) compared, showing more or less equal activity on a weight basis, but I seems to have a significant better performance per silver ion. The $\operatorname{Ag}(\mathrm{I})$ complex also binds more effectively to calf thymus DNA than the dafone ligand itself.
\end{abstract}




\section{Introduction}

Silver has a long history of antimicrobial activity, long predating the discovery of microorganisms, ${ }^{1}$ and before the advent of modern antibiotics silver in various forms was used in several medical indications. Since then its applications have declined, for example the compulsory dropping of $\mathrm{AgNO}_{3}$ solutions in the eyes of newly born babies was discontinued in Sweden 23 years ago. ${ }^{2}$

However, the antimicrobial activity of the silver(I) ion is real, ${ }^{3}$ and use of silver nitrate for the infection prevention and topical treatment of burns and hard-to-heal wounds was revived in the 1960's, although its clinical effects were not undisputed. ${ }^{4}$ The introduction of silver sulphadiazine (also know under different trade names) towards the end of the decade appeared to be an improvement and is still widely used. ${ }^{4}$

In more recent times a number of different wound healing concepts based on silver, including "nanosilver", have been introduced, although conclusive clinical evidence for their efficiency has not always been established. ${ }^{3,5,6}$ While silver preparations are not seriously considered as contenders in the general battle against multiresistant bacteria, ${ }^{7}$ it is however likely that they will continue to play a role in the future, especially in wound healing applications where topical treatment is necessary because of reduced circulation. ${ }^{8,} 9$ In passing, it should be noted that the use of "colloidal silver" and other preparations advocated by "alternative" medicine seem to be without scientific base, for example there are no evidence whatsoever that silver has a positive effect on the human immune system, and silver has, as far as we know, no biological role in humans or any other known biological system. On the contrary, continuous exposure to silver as "nutritional supplement" might have averse effects, despite the known low toxicity of the silver(I) ion. ${ }^{10}$

In the light of this antimicrobial activity, a number of research groups have been searching for new silver(I) complexes to be used in medicine, and not exclusively for wound care. ${ }^{11-32} \mathrm{We}$ have recently showed how ligands based on nicotinic acid (essential for the human body) can give $\mathrm{Ag}(\mathrm{I})$ complexes active against clinical isolates belonging to multiresistant strains of four pathogenic bacteria; S. aureus, S. pyogenes, P. mirabilis and Ps. aeruginosa, and in all cases 
except for $S$. aureus, where the activity was similar, outperforming silver sulphadiazine. ${ }^{33}$

Herein we present the synthesis of bis-4,5-diazafluoren-9-one (= dafone, see Scheme 1) silver(I) nitrate, compound $\mathbf{I}$, and the X-ray single crystal structures of its two crystalline forms $\mathbf{1}$ and $\mathbf{2}$. We comment on the solution chemistry of $\mathbf{I}$ by the use of ${ }^{1} \mathrm{H}-\mathrm{NMR}$ and ESI-MS and compare the antibacterial activity against six different clinically isolated pathogens with those of 15 commercial antibiotics.

We also take this research one step further towards applications by incorporating compound I into three different hydrogels based on dimethacrylated polyethylene glycol, potential carrier materials in a wound dressing, and compare the activity of these gels against Pseudomonas aeruginosa with hydrogels containing $\mathrm{Ag}_{2} \mathrm{SO}_{4}$.

In addition, the binding of dafone and $\mathbf{I}$ to DNA was investigated by linear dichroism (LD).

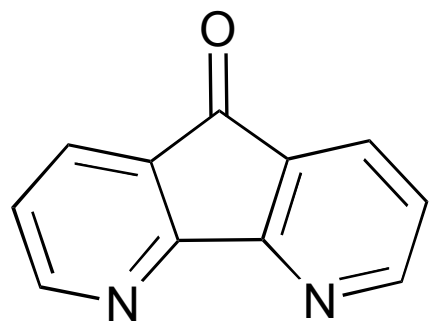

Scheme 1. 4,5-diazafluoren-9-one (dafone)

\section{Results and Discussion}

Synthesis of silver complexes The two crystalline forms $\mathbf{1}$ and $\mathbf{2}$ of this study were synthesised via addition of an ethanol solution of the ligand to silver nitrate dissolved in water under continuous stirring. Both a 1:1 and a 1:2 ratio of metal to ligand gave $30 \%$ yields of 1 or 2 with respect to the limiting starting material, and no other products. The 1:1 proportion was used as we have recently characterised such a "half-naked" $1: 1$ complex both in solution and in the solid state with the related bidentate pyridine-2-carboxaldoxime ligand. ${ }^{34}$

This simple synthetic method was both solvent and temperature dependent. When the 
reaction was performed in an acetonitrile/water mixture at room temperature, only crystals of $\left[\mathrm{Ag}(\text { dafone })_{2}\right] \mathrm{NO}_{3} \cdot \mathrm{H}_{2} \mathrm{O}, 2$ were formed. But when an ethanol/water mixture was used with heating, prismatic crystals of $\left[\mathrm{Ag}(\text { dafone })_{2} \mathrm{NO}_{3}\right], \mathbf{1}$ and needles of $\left[\mathrm{Ag}(\text { dafone })_{2}\right] \mathrm{NO}_{3} \cdot \mathrm{H}_{2} \mathrm{O}, \mathbf{2}$ were collected from the same batch.

Synthesis of silver loaded hydrogels To vary degrees of cross linking of the hydrogels different molecular weights of dimethacrylated PEG (polyethylene glycol) monomers (PEGDMA) were used and three gels containing different ratios of PEGDMA8k, PEGDMA20k, TEGDA (triethylene glycol diacrylate) and PEGDA700 were prepared with water as a solvent. Silver sulphate (2\% and $6 \%$ by weight) and $1(2 \%)$ with $1 \%$ photoinitiator was added and the mixtures cured with a UV Lamp giving nine different gels. Notable differences in appearance of the produced gels were noted: while the gels with $\mathbf{1}$ were white/transparent much like a nonsilver containing gel, the gels with $\mathrm{Ag}_{2} \mathrm{SO}_{4}$ were severely discoloured, see Figure 1.

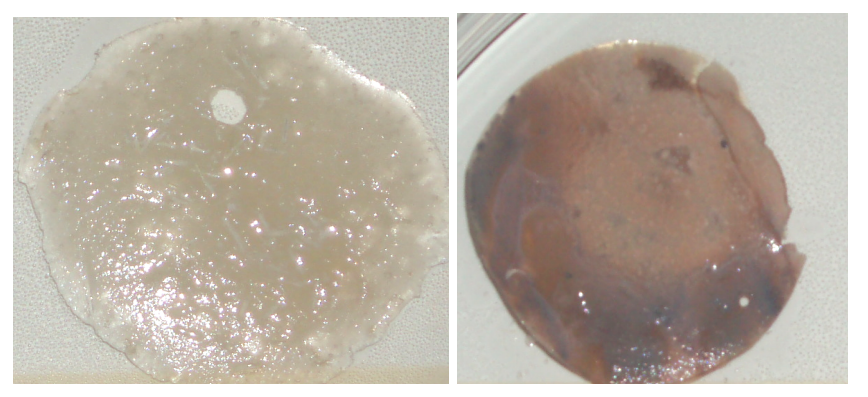

Figure 1. Dimethacrylated PEG gels with left: $2 \%$ 1, right: $2 \% \mathrm{Ag}_{2} \mathrm{SO}_{4}$

Crystal Structures The two structures are strikingly different, we will therefore first present each structure and in conjunction make appropriate comments, and thereafter we will bring up the points that are of general interest in dafone coordination chemistry.

Crystallographic data and refinement parameters for crystal forms $\mathbf{1}$ and $\mathbf{2}$ are listed in Table 1, 
and in Scheme 2 we show the principal coordination geometries around the silver ion in the two cases.

Table 1. Crystal data and structure refinement for crystals $\mathbf{1}$ and $\mathbf{2}$. 


\begin{tabular}{|c|c|c|}
\hline & 1 & 2 \\
\hline Formula & $\mathrm{C}_{22} \mathrm{H}_{12} \mathrm{AgN}_{4} \mathrm{O}_{2} \cdot \mathrm{NO}_{3}$ & $\mathrm{C}_{22} \mathrm{H}_{14} \mathrm{AgN}_{4} \mathrm{O}_{2} \cdot \mathrm{NO}_{3} \cdot \mathrm{H}_{2} \mathrm{O}$ \\
\hline M & 534.24 & 552.25 \\
\hline $\mathrm{T}$ & $153(2) \mathrm{K}$ & $153(2) \mathrm{K}$ \\
\hline Crystal system & Triclinic & Triclinic \\
\hline Space group & P-1 (No.2) & P-1 (No.2) \\
\hline \multirow[t]{6}{*}{ Unit cell } & $a=8.1091(4) \AA$ & $\mathrm{a}=7.4881(10) \AA$ \\
\hline & $\mathrm{b}=10.3382(5) \AA$ & $\mathrm{b}=11.3498(15) \AA$ \\
\hline & $\mathrm{c}=12.6053(6) \AA$ & $\mathrm{c}=13.2259(17) \AA$ \\
\hline & $\alpha=70.963(1)^{\circ}$ & $\alpha=65.156(3)^{\circ}$ \\
\hline & $\beta=81.468(1)^{\circ}$ & $\beta=88.861(3)^{\circ}$ \\
\hline & $\gamma=73.538(1)^{\circ}$ & $\gamma=85.580(3)^{\circ}$ \\
\hline $\mathrm{V}$ & $956.18(8) \AA^{3}$ & $1016.9(2) \AA^{3}$ \\
\hline $\mathrm{Z}$ & 2 & 2 \\
\hline$\rho / \mathrm{g} \mathrm{cm}^{-3}$ & $1.856 \mathrm{Mg} / \mathrm{m}^{3}$ & $1.804 \mathrm{Mg} / \mathrm{m}^{3}$ \\
\hline$\mu / \mathrm{mm}^{-1}$ & $1.105 \mathrm{~mm}^{-1}$ & $1.045 \mathrm{~mm}^{-1}$ \\
\hline Measured reflec. & 13493 & 12668 \\
\hline Unique reflec. & $4741[\mathrm{R}(\mathrm{int})=0.0364]$ & $4194[\mathrm{R}(\mathrm{int})=0.0476]$ \\
\hline $\mathrm{R}(\mathrm{I}>2 \sigma)$ & $\mathrm{R} 1=0.0327, \mathrm{wR} 2=0.0767$ & $\mathrm{R} 1=0.0434, \mathrm{wR} 2=0.1018$ \\
\hline $\mathrm{R}$ indices (all data) & $\mathrm{R} 1=0.0485, \mathrm{wR} 2=0.0822$ & $\mathrm{R} 1=0.0729, \mathrm{wR} 2=0.1156$ \\
\hline
\end{tabular}



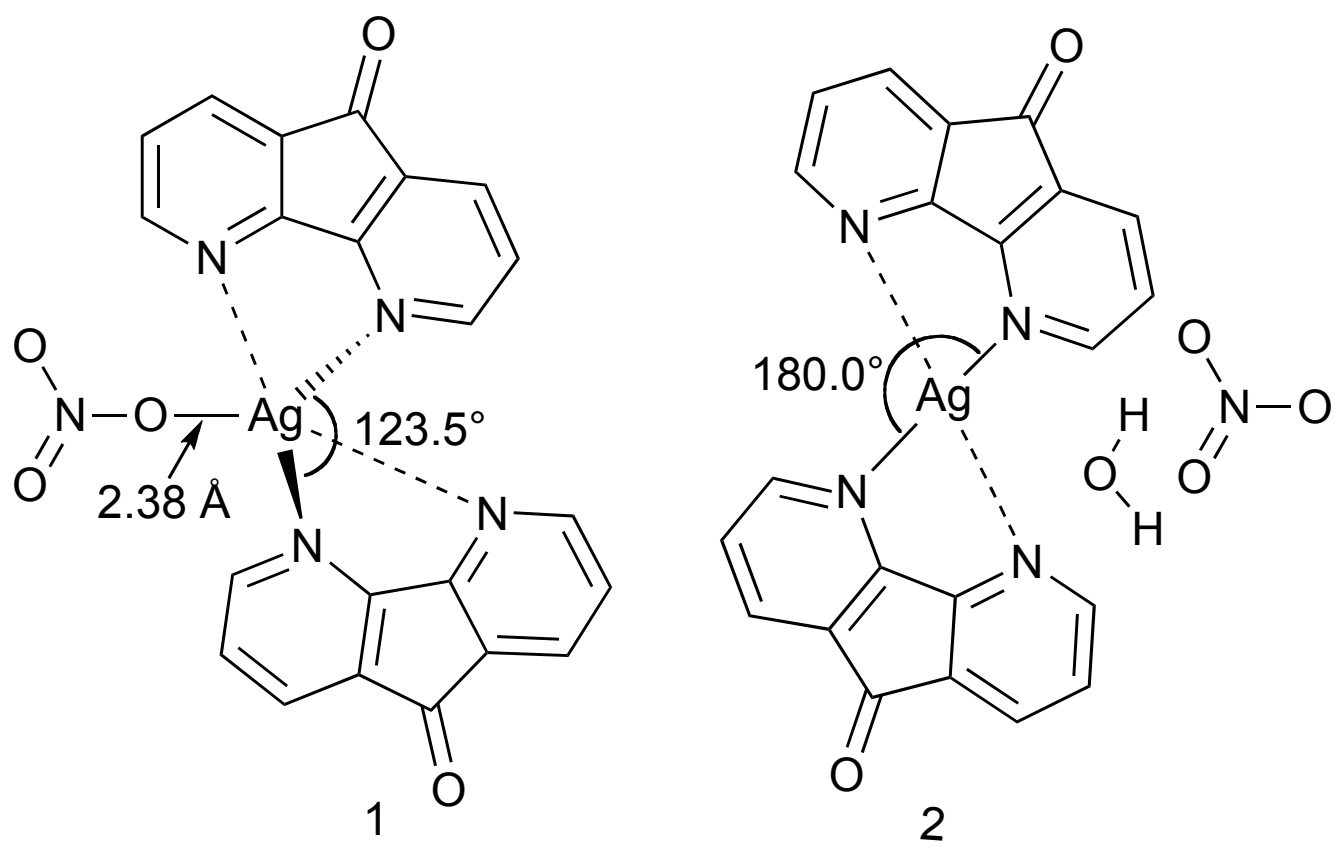

Scheme 2. Relation between $\mathrm{Ag}(\mathrm{I})$ nitrate interactions and N-Ag-N bond angles in $\mathbf{1}$ (left) and 2 (right). The longer, dashed, interactions are 2.567(2) $\AA$, and 2.643(2) $\AA$ in 1 and 2.752(3), 2.699(4) Å in 2.

[Ag(dafone $\left.)_{2} \mathbf{N O}_{3}\right], 1$. The atom numbering for $\mathbf{1}$ is shown in Fig. 2. Silver(I) is coordinated to two dafone moieties each through one of their nitrogen atoms and to one nitrate oxygen atom forming a distorted trigonal planar coordination geometry with bond distances Ag-N 2.385(2), 2.344(2), Ag-O 2.3809(18) $\AA$ and bond angles N-Ag-N 123.45(7), N-Ag-O 121.94(7) and 111.32(7) ${ }^{\circ}$ with the $\mathrm{Ag}(\mathrm{I})$ ion $0.248 \AA$ out of the plane defined by $\mathrm{N} 4 \mathrm{~A} / \mathrm{N} 4 \mathrm{~B} / \mathrm{O} 1$. In addition there are close interactions between the other nitrogen atoms of the dafon ligand at Ag-N5B 2.567(2) $\AA$, and Ag-N5A 2.643(2) A. As a consequence, the two dafone moieties are tilted with a dihedral angle between the planes of $50.75^{\circ}$ giving an overall trigonal-bipyramidal structure with very long axial bonds.

We have previously presented a correlation between $\mathrm{Ag}-\mathrm{O}_{(\mathrm{NO} 3)}$ bond distances and $\mathrm{N}-\mathrm{Ag}-\mathrm{N}$ bond angles. $^{32}$ In 1 both the Ag- $\mathrm{O}_{(\mathrm{NO} 3)}$ bond distance and the $\mathrm{N}-\mathrm{Ag}-\mathrm{N}$ bond angle lie in the normal range for trigonal planar structures. The distortion here is due to the weakly coordinated axial nitrogen atoms. The Ag-N bond distances are comparable to those found for the two structures reported for $\left[\mathrm{Ag}(\text { pdon })_{2}\right] \mathrm{ClO}_{4}[2.261(3), 2.332(4), 2.349(3), 2.453(4)$ and $2.347(3)$, 
$2.362(3) \AA$, where pdon $=1,10$-phenanthroline-5,6-dione. ${ }^{35,36}$

The coordination around silver in $\mathbf{1}$ appears to be rare: we found only five five-coordinated silver complexes in the $\mathrm{CSD}^{37}$ with a $\mathrm{N}_{4} \mathrm{O}$ coordination sphere, and only one three-coordinated silver complex with additional axial N-ligands that has a geometry coming close to the present one. This is catena-(bis(m2-2-Ethyl-3-methylpyrazine-N,N')-bis(4-aminobenzenesulfonate-O)aqua-di-silver(I)) with axial Ag-N distances of $2.78 \AA$ and a close to linear N-Ag-N geometry in the trigonal "base". 38

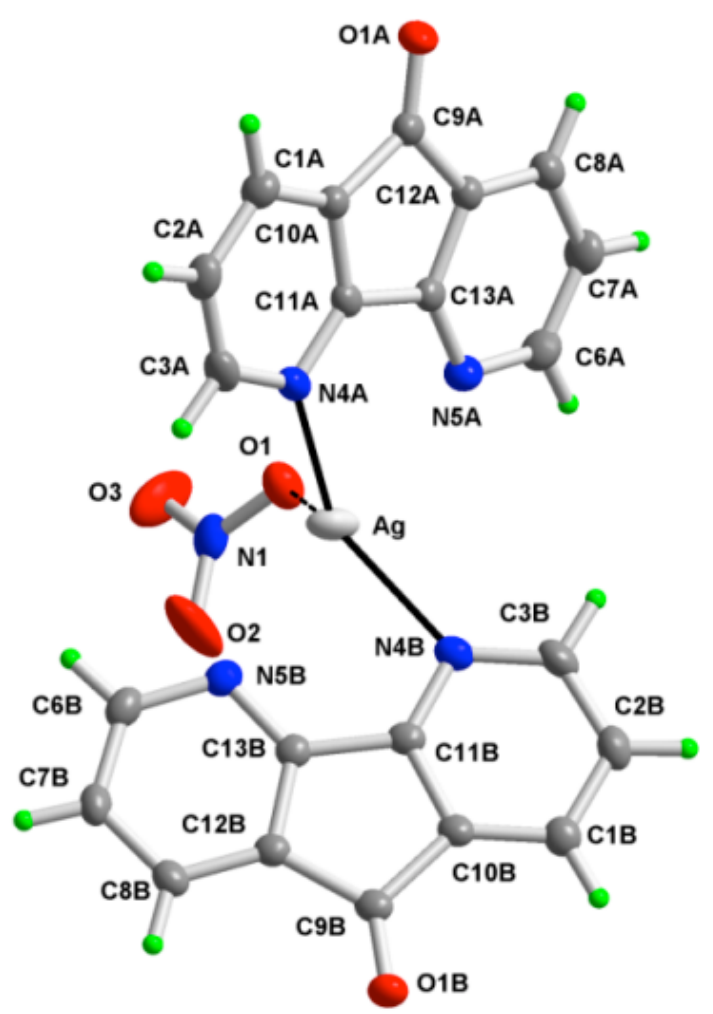

Figure 2. Numbering scheme with atomic displacement ellipsoids drawn at 50\% probability level for crystal form 1.

Hydrogen bonds of the type C-H...O, Table 2, connect the monomeric units of the compound together to form sheets of molecules, see Figure 3. The hydrogen bonds formed through dafone exocyclic oxygen atoms seem to be stronger than those formed through nitrate oxygen atoms, perhaps due to the coordination of the nitrate group to the $\mathrm{Ag}(\mathrm{I})$ centres. 


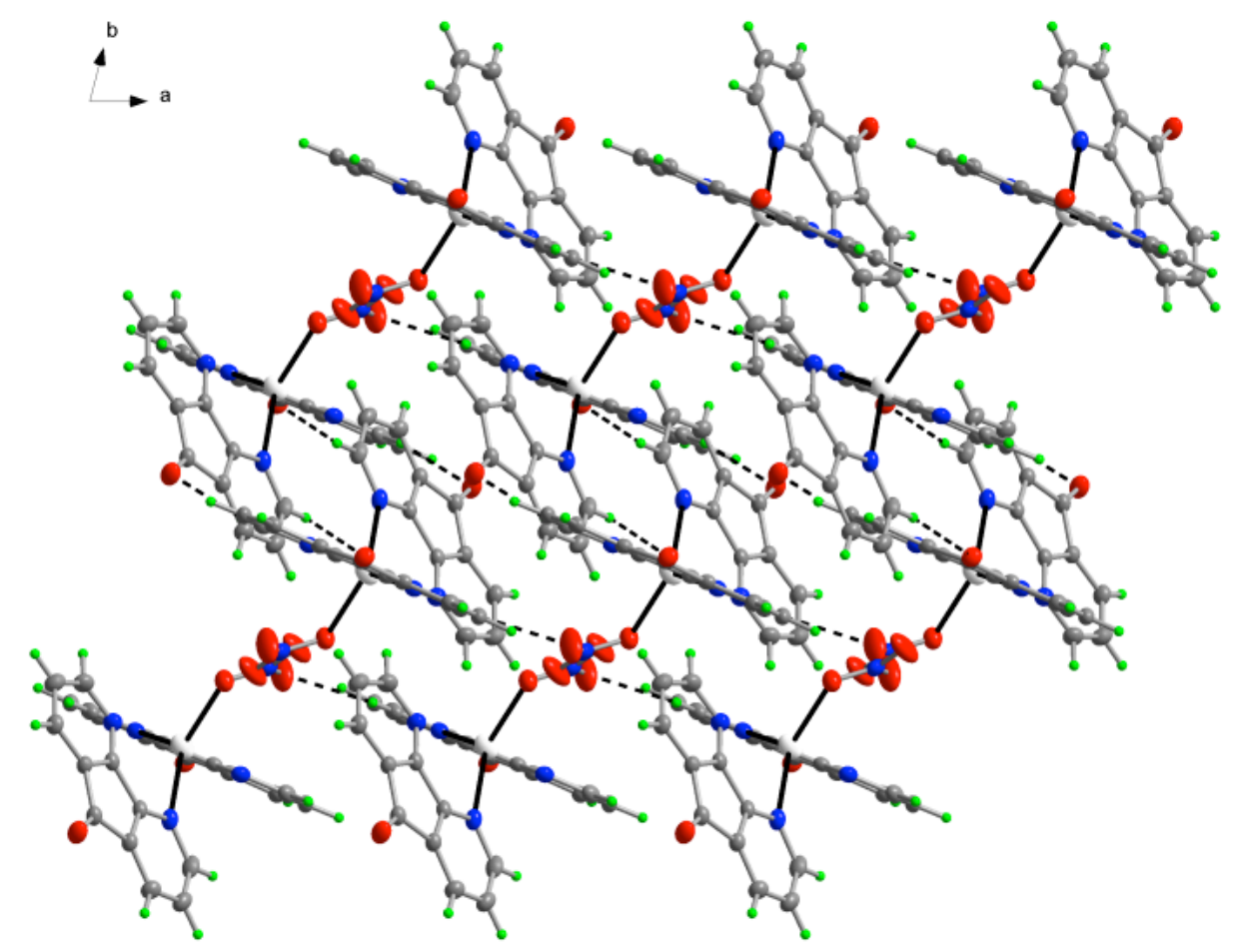

Figure 3. A projection along $c$ axis showing packing of monomeric units of crystal $\mathbf{1}$ via hydrogen bonding.

Table 2. Hydrogen bonds for crystal $\mathbf{1}\left[\AA\right.$ and $\left.^{\circ}\right]$

\begin{tabular}{|c|c|c|c|c|}
\hline D-H...A & \multicolumn{4}{|c|}{$\mathrm{d}(\mathrm{D}-\mathrm{H}) \mathrm{d}(\mathrm{H} \ldots \mathrm{A}) \mathrm{d}(\mathrm{D} \ldots \mathrm{A})<(\mathrm{DHA})$} \\
\hline $\mathrm{C} 2 \mathrm{~A}-\mathrm{H} 2 \mathrm{~A} \ldots \mathrm{O} 1^{\mathrm{i}}$ & 0.95 & 2.57 & $3.306(3)$ & 134 \\
\hline C2B-H2B...O $2^{\mathrm{ii}}$ & 0.95 & 2.57 & $3.470(4)$ & 158 \\
\hline C3A-H3A...O1B & 0.95 & 2.41 & $3.346(3)$ & 168 \\
\hline C3B-H3B...O $2^{\text {iv }}$ & 0.95 & 2.52 & $3.175(3)$ & 127 \\
\hline C6B-H6B...O1A ${ }^{\mathrm{i}}$ & 0.95 & 2.54 & $3.430(3)$ & 156 \\
\hline
\end{tabular}

Symmetry transformations used to generate equivalent atoms:
(i): $-x,-y+1,-z$
(ii): $-\mathrm{x}+1,-\mathrm{y},-\mathrm{z}+1$
(iii): $-\mathrm{x},-\mathrm{y}+1,-\mathrm{z}+1$
(iv): $\mathrm{x}+1, \mathrm{y}, \mathrm{z}$

[Ag(dafone $\left.)_{2}\right] \mathbf{N O}_{3} \cdot \mathbf{H}_{2} \mathbf{O}, 2$. A previous room temperature $(298 \mathrm{~K})$ structure determination for $\mathbf{2}$ was recently reported, ${ }^{39}$ herein we present a more precise structure determination at low temperature 
$(153 \mathrm{~K})$ with atom numbering given in Figure 4. Note that the asymmetric unit contains two half $\left[\mathrm{Ag}(4,5 \text {-diazafluoren-9-one })_{2}\right]$ cations, with the $\mathrm{Ag}$ atoms on independent inversion centres.

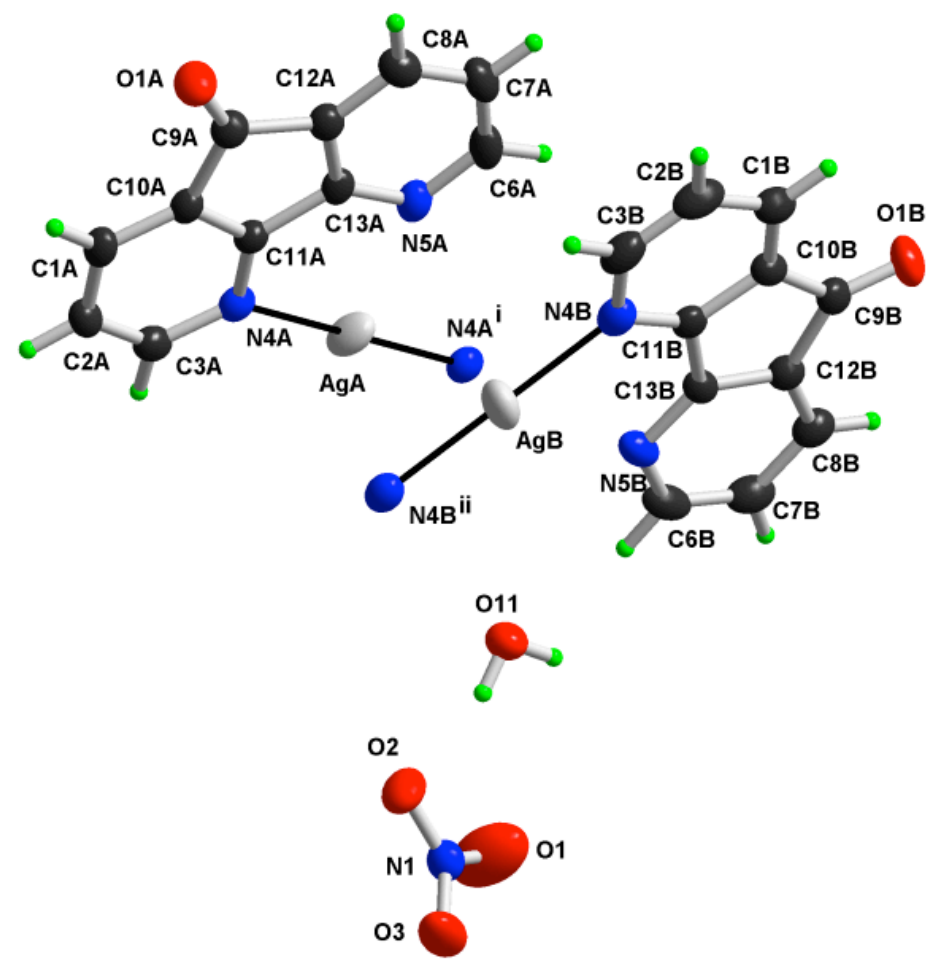

Figure 4. Numbering scheme with atomic displacement ellipsoids drawn at 50\% probability level for crystal form 2 . The symmetry codes are: (i) $-x+1,-y+1,-z$ and (ii) $-x,-y+1,-z$

As per normal, the unit cell volume decreases at low temperature, and the shorter Ag-N bond lengths also decrease by about $2 \%$ which seems reasonable as they are part of a fairly rigid structure (Ag-N 2.222(3), 2.254(3) A, versus 2.180(3), 2.201(4) $\AA$ ). However, the longer interactions increase with the same amount $(2.695(3), 2.650(3) \AA$ versus $2.752(3), 2.699(4) \AA$ ) indicating that these interactions are much weaker. Essentially all other features are the same, and the earlier description of the structure as "pseudo square-planar" is valid, although with an angle of $180^{\circ}$ between the shorter Ag-N bonds, a linear coordination is also a relevant assignment. Interestingly, Biju and Rajasekharan found that the most stable structure calculated by DFT methods was a tetrahedron but that an additional, slightly higher, minima was found for a square planar structure with two very long $(2.8 \AA)$ bonds. $^{39}$ 
As the most important difference between a high and low temperature structure is the much improved hydrogen positions, we report the hydrogen bonding in detail in Table 3 . It is notable that there is no extended pattern of strong hydrogen bonds, probably because only the single water molecule can act as a strong hydrogen bond donor. Instead, these hydrogen bonds link the ketone with the nitrate, and the overall picture is that of close packed columns of planar silver complexes with nitrate ions in-between.

Table 3. Hydrogen bonds for crystal 2 [ $\AA$ and $\left.{ }^{\circ}\right]$

\begin{tabular}{|c|c|c|c|c|}
\hline D-H...A & \multicolumn{4}{|c|}{$\mathrm{d}(\mathrm{D}-\mathrm{H}) \mathrm{d}(\mathrm{H} \ldots \mathrm{A}) \mathrm{d}(\mathrm{D} \ldots \mathrm{A})<(\mathrm{DHA})$} \\
\hline $\mathrm{O} 11-\mathrm{H} 111 \ldots \mathrm{O} 1$ & $0.84(5)$ & $2.36(6$ & $3.103(6)$ & 148(4) \\
\hline O11-H111...O2 & $0.84(5)$ & $2.17(6$ & $2.952(5)$ & $155(5)$ \\
\hline $\mathrm{O} 11-\mathrm{H} 112 \ldots \mathrm{O} 1 \mathrm{~A}^{\mathrm{ii}}$ & $0.83(6)$ & $2.11(6$ & $2.924(5)$ & $167(6)$ \\
\hline C1A-H1A...O $1^{\text {iv }}$ & 0.95 & 2.55 & $3.311(6)$ & 137 \\
\hline C1B-H1B...O2 ${ }^{v}$ & 0.95 & 2.53 & $3.192(5)$ & 127 \\
\hline $\mathrm{C} 2 \mathrm{~A}-\mathrm{H} 2 \mathrm{~A} \ldots \mathrm{O} 1 \mathrm{~B}^{\mathrm{vi}}$ & 0.95 & 2.58 & $3.212(5)$ & 125 \\
\hline $\mathrm{C} 2 \mathrm{~B}-\mathrm{H} 2 \mathrm{~B} \ldots \mathrm{O} 2^{\mathrm{ii}}$ & 0.95 & 2.50 & $3.167(5)$ & 127 \\
\hline C3A-H3A...O $3^{\text {vii }}$ & 0.95 & 2.44 & $3.259(6)$ & 144 \\
\hline C3B-H3B...O11 $1^{\mathrm{ii}}$ & 0.95 & 2.54 & $3.399(6)$ & 151 \\
\hline C6A-H6A...O3 ${ }^{\text {viii }}$ & 0.95 & 2.55 & $3.495(6)$ & 174 \\
\hline С6B-H6B...O11 & 0.95 & 2.46 & $3.393(6)$ & 168 \\
\hline C8B-H8B...O1 ${ }^{\mathrm{ix}}$ & 0.95 & 2.49 & $3.131(7)$ & 125 \\
\hline
\end{tabular}

Symmetry transformations used to generate equivalent atoms:
(i) : $-\mathrm{x}+1,-\mathrm{y}+1,-\mathrm{z}$
(ii) : $-x,-y+1,-z \quad$ (iii): $x, y-1, z+1$
(iv): $\mathrm{x}, \mathrm{y}+1, \mathrm{z}-1$
(v): $\mathrm{x}-1, \mathrm{y}+1, \mathrm{z}(\mathrm{vi}): \mathrm{x}+1, \mathrm{y}, \mathrm{z}-1$
(vii): $-x+1,-y,-z$
(viii): $\mathrm{x}, \mathrm{y}+1, \mathrm{z}$
(ix): $-x,-y,-z+1$ 
Of the 35 reported structures with dafone coordinated to a metal centre via ring nitrogen atoms several have one short and one long $\mathrm{N}$-metal bond distance. For example, a number of $\mathrm{Cu}(\mathrm{II})$ or $\mathrm{Cu}(\mathrm{I})$ dafone compounds with different counter ions have been reported, [Cu(dafone $)_{2} \mathrm{Cl}_{2}$ (dafone $\left.\left.\left.\mathrm{H}^{+} \mathrm{H}_{2} \mathrm{O}\right)_{2}\left(\mathrm{ClO}_{4}\right)_{2}\right]^{40},[\mathrm{Cu} \text { (dafone })_{2}(\text { dicyanamide })_{2}\right]^{41},\left[\mathrm{Cu}(\text { dafone })_{2} \mathrm{Br}_{2}\right]$, $\left.\left.\left.[\mathrm{Cu} \text { (dafone })_{2}\left(\mathrm{H}_{2} \mathrm{O}\right)_{2}\right]\left(\mathrm{NO}_{3}\right)_{2}, \quad[\mathrm{Cu} \text { (dafone })_{2}\left(\mathrm{H}_{2} \mathrm{O}\right)_{2}\right]\left(\mathrm{ClO}_{4}\right)_{2}{ }^{42},[\mathrm{Cu} \text { (dafone })_{2} \mathrm{Br}\right]\left[\mathrm{Cu}(\text { dafone })_{2} \mathrm{I}\right]$ and $\left[\mathrm{Cu}(\text { dafone })_{2}(\mathrm{SCN})\right]_{n}{ }^{43}$, where the short $\mathrm{Cu}-\mathrm{N}$ bond distances are in the range 1.882(6)1.998(2) $\AA$ and the long $\mathrm{Cu}-\mathrm{N}$ bond distances are in the range 2.00(1)- 2.785(6) $\AA$. In the case of the $\mathrm{Mn}(\mathrm{II})$ compound, $\left.\left[\mathrm{MnCl}_{2} \text { (dafone) }\right)_{2}\right] \mathrm{C}_{2} \mathrm{H}_{5} \mathrm{OH}^{44}$, the $\mathrm{Mn}-\mathrm{N}$ bond distances, $2.323(2)$ and 2.445(2) $\AA$, were shorter than those reported for the $\mathrm{Cu}$ compounds. For the zinc(II) compounds, $\left[\mathrm{Zn}(\text { dafone })_{2}\left(\mathrm{H}_{2} \mathrm{O}\right)_{2}\right]\left(\mathrm{ClO}_{4}\right)_{2}{ }^{45}$ and $\left[\mathrm{Zn}(\text { dafone })_{2}\left(\mathrm{H}_{2} \mathrm{O}\right)_{2}\right]\left(\mathrm{NO}_{3}\right)_{2}{ }^{46}$, the $\mathrm{Zn}-\mathrm{N}$ bond distances were 2.151(4), 2.276(4) and 2.201(3), 2.290(3) A, respectively. For all the previously mentioned compounds the coordination geometries around the metal centres were square pyramidal for $\mathrm{Cu}$ (I) compounds and octahedral for $\mathrm{Cu}$ (II), $\mathrm{Mn}$ (II) and $\mathrm{Zn}$ (II). In no case of the above mentioned structures is the exocyclic ketone oxygen of the dafone ligand coordinated to the metal, it is only acting as an acceptor for weak hydrogen bonds.

\section{Solution chemistry of silver complex I}

\section{${ }^{1}$ H-NMR}

Since both crystal forms are only sparingly soluble in hot water, the ${ }^{1} \mathrm{H}-\mathrm{NMR}$ spectra were recorded with DMSO- $d 6$ as a solvent. Compared to the free ligand in the same solvent, complex-induced shifts of about 0.04-0.05 ppm for para- and meta-protons were observed, see Table 4.

Table 4. ${ }^{1} \mathrm{H}-\mathrm{NMR}$ chemical shifts for compound $\mathbf{I}$ 


\begin{tabular}{lll} 
Assignment & $\delta(\mathrm{ppm})$ dafone & $\delta(\mathrm{ppm}) \mathbf{I}$ \\
\hline meta $-\mathrm{H}$ & $7.520(\mathrm{q}, 4 \mathrm{H})$ & $7.566(\mathrm{q}, 4 \mathrm{H})$ \\
para $-\mathrm{H}$ & $8.104(\mathrm{q}, 4 \mathrm{H})$ & $8.143(\mathrm{q}, 4 \mathrm{H})$ \\
ortho-H & $8.811(\mathrm{q}, 4 \mathrm{H})$ & $8.818(\mathrm{q}, 4 \mathrm{H})$ \\
\hline
\end{tabular}

\section{Electrospray ionization mass spectrometry (ESI-MS)}

High-resolution ESI-MS was used to investigate the different ionic species present in solution, also giving clues about the stability of the compound under these experimental conditions (spraying, vaporisation and ionisation). A very strong peak at $m / z 471.0051$ was observed for compound $\mathbf{I}$, consistent with the theoretical $\mathrm{m} / \mathrm{z}$ calculated for the cation $\left[\mathrm{Ag}(\text { dafone })_{2}\right]^{+}(\mathrm{m} / \mathrm{z}$ 471.0006 for $\mathrm{C}_{22} \mathrm{H}_{12} \mathrm{~N}_{4} \mathrm{O}_{2} \mathrm{Ag}_{1}$ ), confirming the presence of such ions in solution. Also, the observation of a characteristic ${ }^{107} \mathrm{Ag} /{ }^{109} \mathrm{Ag}$ isotopic peak doublet ( 52:48) further identified this compound. No other ions were observed in the ESI-MS spectra. The same peak was also observed after the addition of a high concentration $\mathrm{NH}_{4} \mathrm{Cl}$ solution, which suggests that the stability of the Ag-dafone complex is much greater than the affinity of $\mathrm{Ag}^{+}$ions for the $\mathrm{Cl}^{-}$ions, although we could see some turbidity formed in this experiment.

\section{Antimicrobial activity}

Complex $I$ in solution The MIC values, or minimum inhibition concentrations, against six different clinically isolated pathogens were investigated in DMSO for $\mathbf{I}$ and 15 commercial antibiotics, see Table 5. 
Table 5 Activities against diabetic foot bacteria for $\mathbf{I}$ as MIC $(\mu \mathrm{g} / \mathrm{ml})$ values compared with some commercial antibiotics.

\begin{tabular}{|c|c|c|c|c|c|c|c|c|}
\hline \multirow[b]{3}{*}{ Antibiotic group } & \multirow[b]{3}{*}{ Antibiotic } & \multicolumn{7}{|c|}{ Organisms } \\
\hline & & \multicolumn{2}{|c|}{ Gram-positive } & \multicolumn{5}{|c|}{ Gram-negative } \\
\hline & & 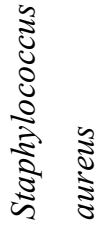 & 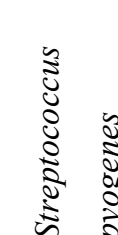 & 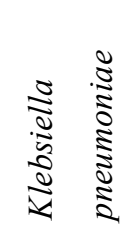 & $\begin{array}{rr} & \vdots \\
\vdots & \vdots \\
0 & \vdots \\
0 & \vdots \\
0 & \vdots \\
0 & \vdots\end{array}$ & 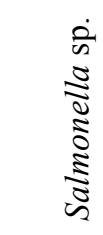 & & 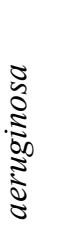 \\
\hline \multirow{6}{*}{ Penicillin $^{1}$} & Amoxicillin & $>256^{4}$ & $>256$ & $>256$ & $>256$ & $>256$ & 1 & \\
\hline & E-Mox & $>256$ & $>256$ & $>256$ & $>256$ & $>256$ & 2 & \\
\hline & Ultracillin & 3 & $>256$ & $>256$ & $>256$ & $>256$ & 3 & \\
\hline & Tienam & 3 & $>256$ & $>256$ & $>256$ & $>256$ & 6 & \\
\hline & Unasyn & 4 & $>256$ & $>256$ & $>256$ & $>256$ & 4 & \\
\hline & Sulbin & 1 & $>256$ & $>256$ & $>256$ & $>256$ & 1 & \\
\hline \multirow{6}{*}{ Cephalosporines $^{1}$} & Velocef & 1 & $>256$ & $>256$ & $>256$ & $>256$ & 1 & \\
\hline & Cefadrin & 3 & $>256$ & $>256$ & $>256$ & $>256$ & 4 & \\
\hline & Zinnat & 6 & $>256$ & $>256$ & $>256$ & $>256$ & 5 & \\
\hline & Claforan & 1 & $>256$ & $>256$ & 200 & $>256$ & 1 & \\
\hline & Fortum & 3 & 128 & 4 & 72 & 96 & 8 & \\
\hline & Cefazone & 16 & $>256$ & 200 & $>256$ & 128 & 2 & \\
\hline \multirow{2}{*}{ Aminoglycosides ${ }^{2}$} & Streptomycin & 3 & 72 & $>256$ & 128 & 200 & 3 & \\
\hline & Amikin & 6 & 128 & 12 & 200 & $>256$ & 12 & \\
\hline \multirow[t]{2}{*}{ Glycopeptides $^{3}$} & Vancomycin & 200 & $>256$ & $>256$ & $>256$ & $>256$ & 200 & \\
\hline & Compound I & 6 & 128 & 4 & 4 & 72 & 72 & \\
\hline
\end{tabular}

${ }^{1}$ Used for a wide range of infections, mainly works through disrupting the synthesis of the peptidoglycan layer of bacterial cell wall; ${ }^{2}$ Used for infections caused by Gram negative bacteria such as Eschericia coli and Klebsilla particularly Pseudomonas aeruginosa, these molecules bind to the bacterial $30 \mathrm{~S}$ and $50 \mathrm{~S}$ ribosomal subunit causing misreading of mRNA leaving the bacteria unable to synthesize proteins vital to its growth. ${ }^{3}$ Have the same mode of action as $\beta$-lactam antibiotics inhibiting peptidoglycan synthesis. ${ }^{4}>256=$ resistant $(0 \mathrm{~mm}$ inhibition zone).

Compound I shows a wide spectrum of antibacterial activity against the tested bacterial strains, comparable to the broad spectrum Fortum and Amikin antibiotics, and was significantly more active on a $\mathrm{mg} / \mathrm{ml}$ basis against $P$. mirabilis (MIC value $4 \mu \mathrm{g} / \mathrm{ml}$ compared to $72 \mu \mathrm{g} / \mathrm{ml}$ for the best performing commercial agent Fortum) and also highly active against K. pneumoniae. The results listed in Table 5 confirm that most of the bacterial strains used in this test are completely 
resistant against most of the antibiotics, especially $\beta$-Lactam antibiotics.

In an additional experiment the dafone ligand by itself proved to be without any antibacterial effect.

While one should remember that MIC values are strictly not comparable between different tests as the strains of the micro-organisms are likely different, it is still necessary to discuss our results in the light of other silver(I) complexes synthesised and tested.

Thus, Nomiya et al. reported the antibacterial properties for a large number of $\operatorname{Ag}(\mathrm{I}) \ldots \mathrm{N}$ compounds. Complexes with imidazole, L-histidine, 1,2,4-triazole and tetrazole showed good activities against both $S$. aureus and Ps. aeruginosa (MIC 8-16 $\mu \mathrm{g} / \mathrm{mL}$ ) when compared to the activities of $\mathrm{AgNO}_{3}$ (MIC $62.5 \mu \mathrm{g} / \mathrm{mL}$ for both bacteria) while the compound $[\mathrm{Ag}(1,2,3-$ triazole) $]_{n}$ showed no activity against any bacteria. ${ }^{47}$

Zhang et al tested three $\left[\operatorname{Ag}((8 \text {-pyridin-3-yl)methylthio)qinoline })]^{+}\right.$compounds with different counter ions and recorded higher activities for $\mathrm{CF}_{3} \mathrm{CO}_{2}{ }^{-}$against $S$. aureus and PS. aeruginosa in comparison to both $\mathrm{NO}_{3}{ }^{-}$and $\mathrm{CF}_{3} \mathrm{SO}_{3}{ }^{-}{ }^{48}$

Our research group recently reported $\mathrm{Ag}(\mathrm{I})$ compounds with pyridine derivatives showing a broad spectrum activity against a number of bacterial strains. ${ }^{32}$ Compounds $[$ Ag(quinoxaline $)]_{\mathrm{n}}\left(\mathrm{NO}_{3}\right)_{n}$ and $\left[\mathrm{Ag}_{3}(2 \text {-aminopyridine })_{4}\right]\left(\mathrm{NO}_{3}\right)_{3}$ gave high activities against $P$. mirabilis (MIC $16 \mu \mathrm{g} / \mathrm{mL}$ ), Salmonella typhi (MIC $8 \mu \mathrm{g} / \mathrm{mL}$ ) and against Ps. aeruginosa (MIC 4 and $8 \mu \mathrm{g} / \mathrm{mL}$, respectively), and $\left[\mathrm{Ag}_{4}(3 \text {-aminopyridine })_{4}\left(\mathrm{NO}_{3}\right)_{4}\right]_{n}$ against Klebsiella pneumoniae (MIC $16 \mu \mathrm{g} / \mathrm{mL}$ ). We also screened $\mathrm{Ag}(\mathrm{I})$ nicotinate compounds for over 12 different antibiotic resistant clinical isolates and $\left[\mathrm{Ag}_{2}-\mu-\mathrm{O}, \mathrm{O}^{\prime}(2 \text {-aminonicotinium })_{2}\left(\mathrm{NO}_{3}\right)_{2}\right]_{n}$ and $\left[\mathrm{Ag}(\text { isonicotinamide })_{2}-\mu-\mathrm{O}, \mathrm{O}^{\prime}\left(\mathrm{NO}_{3}\right)\right]_{2}$ showed considerable activity against Ps. aeruginosa (MIC 2-8 $\mu \mathrm{g} / \mathrm{mL}),\left[\mathrm{Ag}(\text { ethyl nicotinate) })_{2}\right]\left(\mathrm{NO}_{3}\right)$ against $S$. aureus (MIC 4-16 $\mu \mathrm{g} / \mathrm{mL}$ ) and $S$.

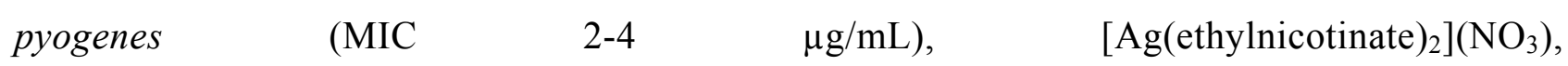
$\left[\mathrm{Ag}(\text { methylisonicotinate })_{2}\left(\mathrm{H}_{2} \mathrm{O}\right)\right]\left(\mathrm{NO}_{3}\right)$ and $\left[\mathrm{Ag}(\text { ethylisonicotinate })_{2}\left(\mathrm{NO}_{3}\right)\right]$ showed remarkable activities against $P$. mirabilis (MIC $1-16 \mu \mathrm{g} / \mathrm{mL}$ ). ${ }^{33}$ The $\mathrm{Ag}(\mathrm{I})$ complexes of the chelating ligand pyridine-2-carboxaldoxime and the substituted aminopyridine 2-amino-3-methylpyridine 
considerable activity against $S$. lutea, $M$. lutea and $S$. aureus and against the yeast Candida albicans. ${ }^{34}$

We also note that the related compound $\left[\mathrm{Ag}(1,10 \text {-phenanthroline-5,6-dione })_{2}\right] \mathrm{ClO}_{4}$ was reported to be very active against the yeast $C$. Albicans. ${ }^{49}$

Complex I in hydrogels The nine hydrogels prepared were tested on tryptic soy agar plates containing a culture of Pseudomonas aeruginosa (ATCC 15442). The zones of inhibition after $22 \mathrm{~h}$ incubation were measured and are presented in Figure 5.

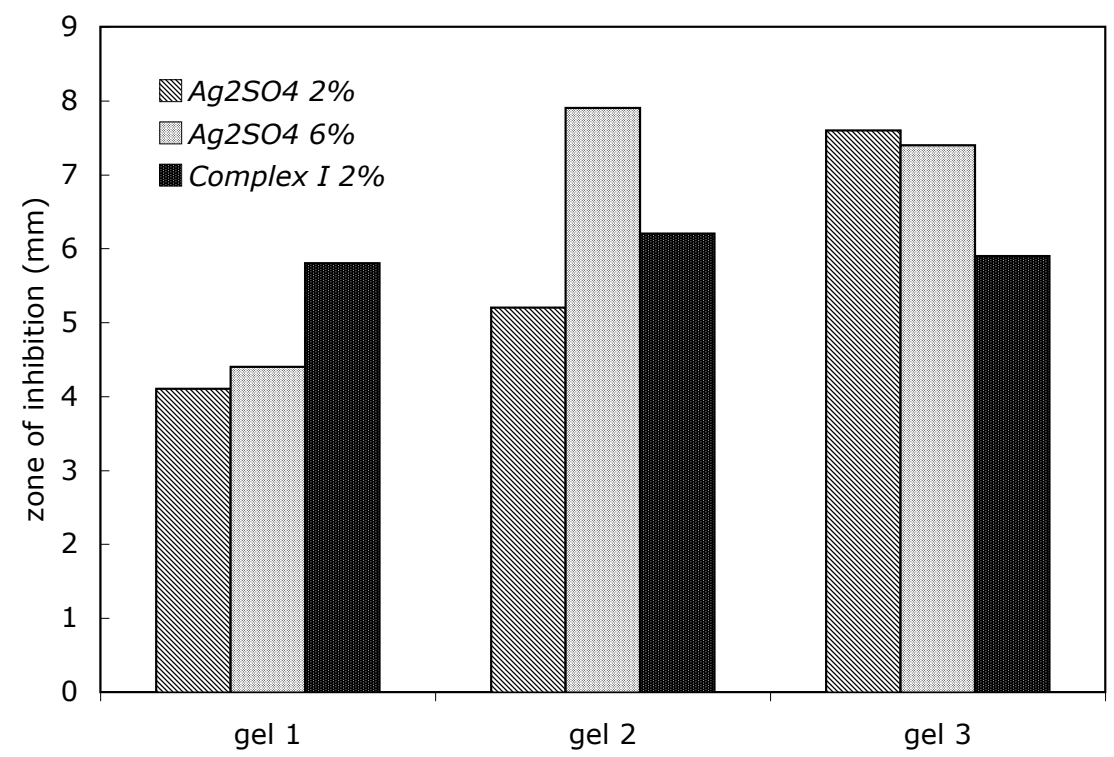

Figure 5. Comparing the zones of inhibition of Pseudomonas aeruginosa around samples of dimethacrylated PEG gels $1-3$ of $\mathrm{Ag}_{2} \mathrm{SO}_{4},(2 \%$ and $6 \%)$ and $1(2 \%)$ after $22 \mathrm{~h}$ incubation on agar plates.

We note that these data are preliminary and only give a rough guide to the potential antibacterial efficiency of the various preparations. However, it seems that complex I has advantages compared to the simple silver salt. The discolouring of the silver sulphate gels may actually have little effect on silver release, and is likely the result of a reduction process initiated by the UV curing. More importantly, the consistent results of the three gels containing 
the dafone complex suggest a uniform distribution of the silver ion in the gels. On the contrary, especially the result indicating a higher activity of a lower level of $\mathrm{Ag}_{2} \mathrm{SO}_{4}$, hint at a nonuniform Ag concentration in these gels; possibly related to the discolouring phenomenon. It may well be that the complex bound silver ion is protected from unwanted side reactions during the polymerization step. Finally, allowing for a rather large experimental error it may be concluded that $2 \% \mathrm{Ag}_{2} \mathrm{SO}_{4}$ and 2\% I has approximately the same inhibition effect. Considering that $\mathrm{Ag}_{2} \mathrm{SO}_{4}$ contains $69 \%$ silver and compound I only $22 \%$ we note that the antibacterial efficiency per silver ion is likely greater for $\mathbf{I}$.

\section{DNA Binding}

The antibacterial action of silver ions is not known in any detail on the molecular level, but (1) interference with electron transport, (2) interaction with cell membrane and (3) binding to DNA have been proposed. ${ }^{50}$ That silver(I) ions in the form of silver nitrate does indeed interact with DNA was shown more than 40 years ago, ${ }^{51,52}$ and, as was shown for silver sulfadiazine, compounds of silver(I) may gave different effects. ${ }^{53}$

Thus the DNA binding properties of the silver-dafone complex I were investigated using flow LD and calf thymus DNA. Since LD is a measure of the differential absorption of parallel and perpendicular light relative to an orientation axis, only molecules that bind to DNA aligned in the shear flow will show an LD signal. Fig. 6 (A) shows LD spectra of DNA alone and with addition of compound $\mathbf{I}$ at different concentrations. The negative peak at $260 \mathrm{~nm}$ originates from the nucleobases that are perpendicular to the helix axis in B-form DNA. This DNA peak is clearly shifted towards longer wavelength and the signal is decreased with increasing concentration of added silver compound. This confirms that the compound binds to DNA, and the effect is similar to what has been observed for titration of silver nitrate to ctDNA $^{52}$ indicating that the silver compound also alter the DNA structure.

Fig. 6 (B) presents the LD of DNA alone (solid line) and the different LD signals of DNA bound I (dotted line) and dafone ligand (dashed line). In the region around $240 \mathrm{~nm}$, where the ligand and the complex show strong absorptions (grey line), both the ligand by itself and the compound show a positive contribution to the LD signal concluding that they bind to DNA. However, this signal is significantly altered by the $\mathrm{Ag}(\mathrm{I})$ complex, indicating a strong 
perturbation of DNA conformation, not observed when only the ligand is bound. Further, the same LD spectrum of the complex and DNA shows a negative peak around $320 \mathrm{~nm}$, originating from dafone, which is much weaker for the dafone ligand alone (inset), proving that the complex has a stronger DNA binding than the ligand itself. (Although we should add that a synergistic effect involving silver ions in one site and an uncoordinated dafone ligand in another cannot be completely ruled out.)
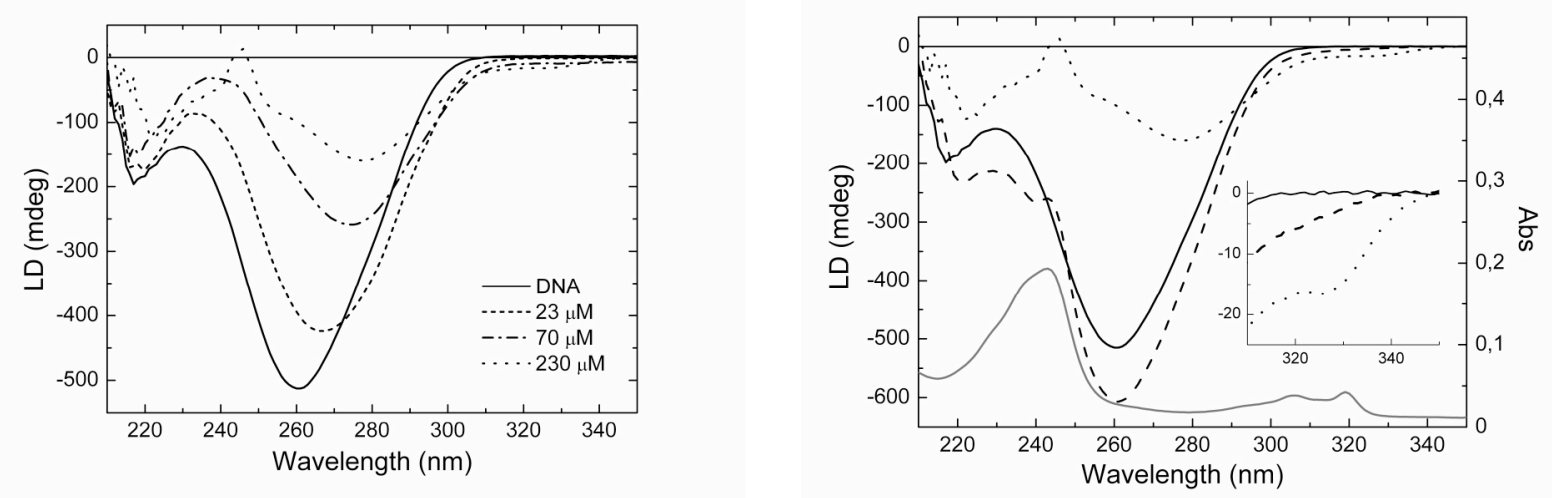

Fig. 6 (A) Linear dichroism (LD) spectra of DNA titrated with $\left[\mathrm{Ag}\left(4,5\right.\right.$-diazafluoren-9-one $\left.{ }_{2} \mathrm{NO}_{3}\right]$, 1. (B) LD spectra of DNA (solid line) and DNA with addition of $\mathbf{1}$ (dotted line) or the dafone ligand alone (dashed line). An enlargement of the graph at $310-350 \mathrm{~nm}$ is shown as inset. The concentrations used are: DNA $100 \mu \mathrm{M}$; dafone $230 \mu \mathrm{M}$; compound I $200 \mu \mathrm{M}$. A representative UV absorption spectrum of $\mathbf{I}$ in water is shown in grey.

\section{Conclusions}

We have further showed that unusual coordination geometries are often found with the dafon ligand, and we have characterised the $\left[\mathrm{Ag}(\text { dafon })_{2}\right]^{+}$complex in solution by NMR and ESIMS. LD proves that both the dafone ligand alone and the $\mathrm{Ag}(\mathrm{I})$ dafone complex bind to DNA, and the increase in dafone LD signal when silver is present indicate a strong silver-dafone DNA interaction. In a comparative study we have moreover shown that in vitro the $\mathrm{Ag}(\mathrm{I}) \mathrm{dafone}$ complex is significantly more active on a $\mathrm{mg} / \mathrm{ml}$ basis against a multi drug resistant strand of $P$. mirabilis than any of the 15 tested antibiotics (MIC value $4 \mu \mathrm{g} / \mathrm{ml}$ compared to $72 \mu \mathrm{g} / \mathrm{ml}$ for the best performing commercial agent Fortum) and also highly active against K. pneumoniae. Furthermore, in a preliminary study of hydrogels as possible carrier materials (for potential use in a real wound dressing), the $\left[\mathrm{Ag}(\text { dafon })_{2}\right]^{+}$complex both gives a significantly better 
appearance of the gel with no discolouration, and approximately the same antibacterial effect compared to $\mathrm{Ag}_{2} \mathrm{SO}_{4}$ but with only $1 / 3$ of the silver content by weight.

\section{Experimental details}

\section{Materials and methods}

All chemicals were reagent grade and used without further purification. Silver sulphate with an average particle size of 4.723 microns was purchased from Alfa Aesar.

\section{X-ray crystallography}

Crystallographic measurements were made on a Siemens Smart CCD diffractometer with graphite monochromated Mo-K $\alpha$ radiation at $153 \mathrm{~K}$. The structures were solved by direct methods and subsequent full-matrix least-squares refinement, including anisotropic thermal parameters for all non-hydrogen atoms. The water $\mathrm{H}$ atoms in $\mathbf{2}$ were refined isotropically; all other $\mathrm{H}$ atoms were allowed for as riding with $\mathrm{C}-\mathrm{H} 0.95 \AA$. The calculations were carried out with the SHELXTL program package. CCDC reference numbers 733754 and 733755 . For crystallographic data in CIF or other electronic format see DOI: $x x x x \times x \times x x$

\section{Synthesis}

\section{$\left[\mathrm{Ag}(\text { dafone })_{2} \mathrm{NO}_{3}\right], 1$ and $\left[\mathrm{Ag}(\text { dafone })_{2}\right] \mathrm{NO}_{3} \cdot \mathrm{H}_{2} \mathrm{O}, 2$}

To an aqueous solution $\left(4 \mathrm{~cm}^{3}\right)$ of $\mathrm{AgNO}_{3}(0.170 \mathrm{~g}, 1 \mathrm{mmol})$, an ethanolic solution $\left(4 \mathrm{~cm}^{3}\right)$ of 4,5-diazafluoren-9-one ligand, (dafone), (0.360 g, $2 \mathrm{mmol})$ was added. The turbid yellow solution was then heated until boiling with continuous stirring. The final clear yellow solution was allowed to stand at room temperature. Yellowish crystals suitable for X-rays measurements of 1 were filtered off first upon slow cooling down of the solution. Needles of crystal $\mathbf{2}$, suitable for X-rays measurements were collected as well one day later from the former filtrate with. The total yield was $0.16 \mathrm{~g}(30 \%)$. Elemental analysis for crystal 1: Calculated: C, 49.46; H, 2.26 and N, 13.11. Found: C, 49.51; H, 2.45 and N, 12.91. FTIR, $\mathrm{KBr}\left(\mathrm{cm}^{-1}\right)$ (v, very; s, strong; $\mathrm{m}$, medium; w, weak; br, broad; sh, shoulder): crystal 1: 361 s, 370 m, 392 s, 412 w, 422 w, 429 w, $518 \mathrm{~m}, 551 \mathrm{w}, 620 \mathrm{~m}, 633 \mathrm{~m}, 668 \mathrm{~m}, 685 \mathrm{~m}, 717 \mathrm{~s}, 759 \mathrm{vs}, 806 \mathrm{~m}, 824 \mathrm{~m}, 834 \mathrm{~s}, 915 \mathrm{~s}, 1030 \mathrm{~m}$, 
1081 s, 1099 s, 1150 m, 1258 s, 1308 s br, 1384 vs br, 1402 vs br, 1463 s, 1558 vs, 1588 vs, 1716 vs, 1832 m, 2359 s, 3035 vs, 3418 s br. Crystal 2: 357 vs, 370 m, 391 m, 405 w, 412 w, $430 \mathrm{w}, 517 \mathrm{~m}, 550 \mathrm{w}, 620 \mathrm{~m}, 668 \mathrm{~m}, 684 \mathrm{~m}, 716 \mathrm{~s}, 758 \mathrm{vs}, 824 \mathrm{~m}, 833 \mathrm{~m}, 915 \mathrm{~s}, 1029 \mathrm{~m}, 1081$ m, 1099 s, 1149 m, 1260 s, 1271 s, 1384 vs, 1402 vs sh, 1462 s, 1559 vs, 1588 s, 1596 s, 1717 vs, $1831 \mathrm{~h} \mathrm{w}, 2342$ s, 2360 s, $2426 \mathrm{~m}, 2983$ s, 3033 s, $3062 \mathrm{~m} .{ }^{13} \mathrm{C}-\mathrm{NMR}$ chemical shifts in DMSO- $d 6$ as $\delta(\mathrm{ppm})$ : ( $m=$ meta; $p=$ para; $o=$ ortho relative to one pyridine ring $\mathrm{N}$-atom): $126.39(m), 129.39(m), 132.68(p), 155.29(o), 162.5(o)$ and $190.00(\mathrm{C}=\mathrm{O})$.

\section{Preparation and characterization of dimethacrylated PEG:s}

Before use, PEG8k (Fluka) and PEG20k (Fluka) were dissolved in toluene and the solutions were heated to azeotropically dehydrate the PEG solution.

PEGDMA 8k 19.964g (1 eq, 1mmol) PEG8k was dissolved in $200 \mathrm{ml}$ toluene and heated until the toluene volume had been reduced by half, and allowed to cool down. $7.767 \mathrm{~g}$ (20 eq, $20 \mathrm{mmol}$ ) methacrylate anhydride dissolved in $15 \mathrm{ml}$ dichloromethane, an additional amount of $20 \mathrm{ml}$ dichloromethane, $187 \mathrm{mg}(0.8 \mathrm{eq}, 0.8 \mathrm{mmol})$ DMAP and $4 \mathrm{ml}$ pyridine were then added to the cooled solution. The mixture was left over night in room temperature while stirred. ${ }^{1} \mathrm{H}$ NMR chemical shifts in $\mathrm{CDCl}_{3}$ : 1.92 (broad, $\mathrm{CH}_{3}$ ), 3.62 (broad, $\mathrm{CH}_{2}$ of main PEG chain), 4.28 (broad, $\mathrm{CH}_{2}$ close to methacrylate), 5.56 (broad, $=\mathrm{CH}_{2}$ of methacrylate), 6.11 (broad, $=\mathrm{CH}_{2}$ of methacrylate)

PEGDMA 20k 20.023g (1 eq, 1mmol) PEG20k was dissolved in $200 \mathrm{ml}$ toluene and heated until the toluene volume had been reduced by half, and allowed to cool down. $3.07 \mathrm{~g}$ (20 eq, $20 \mathrm{mmol}$ ) methacrylate anhydride dissolved in $10 \mathrm{ml}$ dichloromethane, an additional amount of $25 \mathrm{ml}$ dichloromethane, $97 \mathrm{mg}(0.8 \mathrm{eq}, 0.8 \mathrm{mmol})$ DMAP and $4 \mathrm{ml}$ pyridine were added to the cooled solution. The mixture was left over night in room temperature while stirred. ${ }^{1} \mathrm{H}-\mathrm{NMR}$ chemical shifts in $\mathrm{CDCl}_{3}$ : 1.93 (broad, $\mathrm{CH}_{3}$ ), 3.63 (broad, $\mathrm{CH}_{2}$ of main PEG chain), 4.28 (broad, $\mathrm{CH}_{2}$ close to methacrylate), 5.56 (broad, $=\mathrm{CH}_{2}$ of methacrylate), 6.11 (broad, $=\mathrm{CH}_{2}$ of methacrylate)

Gels 1,2 and 3. Three gels containing different ratios of PEGDMA8k, PEGDMA20k, TEGDA (triethylene glycol diacrylate) and PEGDA700 were produced using water as a solvent. Silver 
sulphate was added in the amount of 2 and $6 \mathrm{wt} \%$ and $\left[\mathrm{Ag}(\text { dafone })_{2} \mathrm{NO}_{3}\right]$ was added in the amount of $2 \mathrm{wt} \%$. The photoinitiator $(1 \mathrm{wt} \%)$ was added and the mixtures were stirred in an Ultrasound Bath (Branson 200-Ultrasonic Cleaner) for 5 minutes and thereafter cured using an UVP Blak Ray UV Bench Lamp.

Table 6. Hydrogel compositions

\begin{tabular}{c|ccccc}
\hline Gel & $\begin{array}{c}\text { PEGDMA8k } \\
(w t \%)\end{array}$ & $\begin{array}{c}\text { PEGDMA20k } \\
(w t \%)\end{array}$ & $\begin{array}{c}\text { PEGDA700 } \\
(w t \%)\end{array}$ & $\begin{array}{c}\text { TEGDA } \\
(w t \%)\end{array}$ & $\begin{array}{c}\text { Water } \\
(w t \%)\end{array}$ \\
\hline Gel 1 & 9 & 20 & 1 & - & 70 \\
Gel 2 & 9 & 20 & 0.5 & 0.5 & 70 \\
Gel 3 & - & 20 & 0.5 & 0.5 & 70 \\
\hline
\end{tabular}

\section{Instrumental methods}

\section{IR spectra and elemental analysis}

Infrared spectra were recorded on a Bruker IFS-125 model FT-IR spectrophotometer as KBr pellets. C, H, N analyses were carried out by Mikroanalytisches Laboratorium Kolbe, Mülheim an der Ruhr, Germany.

\section{NMR}

For I ${ }^{1} \mathrm{H}-\mathrm{NMR}$ and ${ }^{13} \mathrm{C}-\mathrm{NMR}$ analyses were made on Varian UNITY and JEOL DELTA_NMR $400 \mathrm{MHz}$ spectrometers at $25^{\circ} \mathrm{C}$ with DMSO-d6 (99.8\% D) as solvent. Chemical shifts are reported in ppm with the solvent as internal standard. For the polymers a Bruker Avance 400 $\mathrm{MHz}$ NMR instrument using $\mathrm{CDCl}_{3}$ as solvent was used.

\section{Electrospray ionization mass spectrometry (ESI-MS)}

High-resolution ESI-MS analyses were performed on a Bruker APEX-Qe hybrid quadrupole Fourier transform ion cyclotron resonance (Q-FT-ICR) mass spectrometer, equipped with an Apollo-II ESI source and a 4.7-T superconducting magnet. The instrument was operated in both positive and negative ion modes. About $1 \mathrm{mg}$ of crystal form 1 was dissolved in $1 \mathrm{ml}$ of DMSO $(2 \mathrm{mM})$, since it is sparingly soluble in water, then $0.1 \mathrm{ml}$ of this solution was diluted with $4 \mathrm{ml}$ $\mathrm{MeOH}$ (the resulting solution is $0.05 \mathrm{mM} \mathrm{Ag}^{+}$tot). This solution was infused into the ESI source at a flow rate of $1.5 \mu 1 / \mathrm{min}$ and positive ions were detected. A solution of $6 \mathrm{mg} \mathrm{NH} 4 \mathrm{Cl}$ in $10 \mathrm{ml}$ 
water $(10 \mathrm{mM})$ was prepared and $1 \mathrm{ml}$ of this solution was added to 1 (DMSO/MeOH diluted solution; the resulting solution is $2 \mathrm{mM} \mathrm{NH}_{4} \mathrm{Cl}$ and $0.04 \mathrm{mM} \mathrm{Ag}^{+}$tot ), infused into the ESI source and both positive and negative ions were detected. As $\mathrm{K}_{\mathrm{sp}}$ for silver chloride is $1.6 \cdot 10^{-10}$ this means that the solubility product was surpassed by at least a factor of 500 . The instrument was operated with Bruker XMASS 7.0.8 software and spectra were processed/analyzed with the use of Bruker DataAnalysis 3.5 software.

\section{Testing of antimicrobial activity}

\section{Compound I}

Antimicrobial activities of compound I were determined according to the recommendations of NCCLS40 by the use of a broth microdilution method. Minimum inhibitory concentrations (MICs) for the tested compounds were conducted using six clinical isolates, Staphylococcus aureus, Klebsiella pneumoniae, Proteus mirabilis, Salmonella sp., Pseudomonas aeruginosa and Streptococcus pyogenes. The test materials were dissolved in DMSO to give a stock solution that was subsequently diluted in the growth medium. The concentration used was $168 \mu \mathrm{g} / \mathrm{disc}$. Bacteria were cultured in Mueller Hinton Broth (MHB) for $24 \mathrm{~h}$ at $35^{\circ} \mathrm{C}$ The MIC values correspond to the lowest concentration that inhibited bacterial growth.

\section{Hydrogels 1-3 with $\mathrm{AgSO}_{4}$ and compound I}

Muller Hilton plates, Tryptic Soy Agar (TSA), Tryptic Soy Broth (TSB), peptone water (PW) were purchased from Bakteriologiska Laboratoriet, Sahlgrenska. The zones of inhibition were measured with a Mitutoyo Absolute Digimatic CD-15CP vernier caliper.

One bead of Pseudomonas aeruginosa (ATCC 15442) was spread on the surface of a TSA plate and incubated in $35^{\circ} \mathrm{C}$ over night. One of the formed colonies was transferred into $3 \mathrm{ml}$ of TSB and thereafter incubated at $35^{\circ} \mathrm{C}$ over night.

The night culture was diluted to $106 \mathrm{cells} / \mathrm{ml}$ in bactopeptone water $(0.85 \% \mathrm{NaCl}$ and $0.1 \%$ peptone water). $0.1 \mathrm{ml}$ of the cell suspension was transferred to each Muller Hilton agar plate (final concentration 105 cells/plate). The gels were gently added to the surface of the agar plate and left at room temperature for 60 minutes before incubation $\left(35^{\circ} \mathrm{C}\right.$ for $\left.22 \mathrm{~h}\right)$. 


\section{DNA interactions measured by Linear Dichroism (LD)}

Linear dichroism is defined as the differential absorption of linearly polarized light parallel and perpendicular to a macroscopic orientation axis,

$$
L D(\lambda)=A_{I I}(\lambda)-A_{\perp}(\lambda)
$$

Samples with calf thymus DNA were oriented in a Couette flow cell with an outer rotating cylinder at a shear gradient of $3100 \mathrm{~s}^{-1}$. LD spectra were measured on a Jasco J-720 CD spectropolarimeter equipped with an Oxley prism to obtain linearly polarized light. ${ }^{54}$ Spectra were recorded between 210 and $350 \mathrm{~nm}$ and corrected for background contribution by subtracting a spectrum collected without rotation of the Couette cell.

\section{Acknowledgements}

This work was supported by Kristina Stenborgs Stiftelse, Magnus Bergvalls stiftelse and Kungliga Vetenskaps och Vitterhetssamhället i Göteborg. The authors thank Mrs. Ritva Romppanen for her skilful technical assistance in ESI-MS measurements and Robert Westlund at The Polymer Factory Sweden AB, Stockholm for support with the synthesis. AAM thanks the NORDFORSK network in Crystal Engineering and Supramolecular Materials for a travel grant to Joensuu.

\section{Notes and references}

$\dagger$ Electronic Supplementary Information (ESI) available: See DOI: 10.1039/b000000x/ 
1. H. J. Klasen, Burns, 2000, 26, 117-130.

2. Nationalencyclopedin, Bra Böcker, Höganäs, 1990-1991.

3. S. Silver, L. T. Phung and G. Silver, J Ind. Microbiol. Biotechnol., 2006, 33, 627-634

4. H. J. Klasen, Burns, 2000, 26, 131-138.

5. S. Silver, Fems Microbiology Reviews, 2003, 27, 341-353.

6. M. N. Storm-Versloot, C. G. Vos, D. T. Ubbink and H. Vermeulen, The Cochrane Library, Topical silver for preventing wound infection, The Cochrane Collaboration, John Wiley \& Sons. Ltd, 2010.

7. ECDC/EMEA JOINT TECHNICAL REPORT The bacterial challenge: time to react EMEA/576176/2009, ISBN 978-92-9193-193-4, doi 10.2900/2518 European Centre for Disease Prevention and Control, 2009.

8. I. Chopra, J. Antimicrob. Chemother., 2007, 59, 587-590.

9. V. Edwards-Jones, Lett. Appl. Microbiol., 2009, 49, 147-152.

10. Colloidal Silver Products, NCCAM Publication No. D209, The National Center for Complementary and Alternative Medicine (NCCAM), USA, http://nccam.nih.gov/health/silver/, Accessed 24th November, 2010

11. M. McCann, B. Coyle, J. Briody, F. Bass, N. O'Gorman, M. Devereux, K. Kavanagh and V. McKee, Polyhedron, 2003, 22, 1595-1601.

12. S. P. Chen, G. Z. Wu and H. Y. Zeng, Carbohydrate Polym., 2005, 60, 33-38.

13. K. Nomiya, A. Yoshizawa, K. Tsukagoshi, N. C. Kasuga, S. Hirakawa and J. Watanabe, J. Inorg. Biochem., 2004, 98, 46-60.

14. N. C. Kasuga, A. Sugie and K. Nomiya, Dalton Trans., 2004, 3732-3740.

15. S. S. Djokic, J. Electrochem. Soc., 2004, 151, C359-C364.

16. M. Devereux, M. McCann, D. O. Shea, R. Kelly, D. Egan, C. Deegan, K. Kavanagh, V. McKee and G. Finn, J. Inorg. Biochem., 2004, 98, 1023-1031.

17. B. Coyle, M. McCann, K. Kavanagh, M. Devereux, V. McKee, N. Kayal, D. Egan, C. Deegan and G. J. Finn, J. Inorg. Biochem., 2004, 98, 1361-1366.

18. S. Abuskhuna, J. Briody, M. McCann, M. Devereux, K. Kavanagh, J. B. Fontecha and V. McKee, Polyhedron, 2004, 23, 1249-1255.

19. I. Tsyba, B. B. K. Mui, R. Bau, R. Noguchi and K. Nomiya, Inorg. Chem., 2003, 42, 80288032.

20. A. Tavman, B. Ulkuseven, S. Birteksoz and G. Otuk, Folia Microbiologica, 2003, 48, 479483. 
21. L. Balogh, D. R. Swanson, D. A. Tomalia, G. L. Hagnauer and A. T. McManus, Nano Letters, 2001, 1, 18-21.

22. B. Ulkuseven, A. Tavman, G. Otuk and S. Birteksoz, Folia Microbiologica, 2002, 47, 481487.

23. B. S. Creaven, D. A. Egan, K. Kavanagh, M. McCann, M. Mahon, A. Noble, B. Thati and M. Walsh, Polyhedron, 2005, 24, 949-957.

24. A. Melaiye, Z. H. Sun, K. Hindi, A. Milsted, D. Ely, D. H. Reneker, C. A. Tessier and W. J. Youngs, J. Am. Chem. Soc., 2005, 127, 2285-2291.

25. H. V. R. Dias, K. H. Batdorf, M. Fianchini, H. V. K. Diyabalanage, S. Carnahan, R. Mulcahy, A. Rabiee, K. Nelson and L. G. van Waasbergen, J. Inorg. Biochem., 2006, 100, 158-160.

26. R. Noguchi, A. Hara, A. Sugie and K. Nomiya, Inorg. Chem. Comm., 2006, 9, 60-63.

27. E. Barreiro, J. S. Casas, M. D. Couce, A. Sanchez, R. Seoane, J. Sordo, J. M. Varela and E. M. Vazquez-Lopez, Eur. J. Med. Chem., 2008, 43, 2489-2497.

28. K. M. Hindi, T. J. Siciliano, S. Durmus, M. J. Panzner, D. A. Medvetz, D. V. Reddy, L. A. Hogue, C. E. Hovis, J. K. Hilliard, R. J. Mallet, C. A. Tessier, C. L. Cannon and W. J. Youngs, J. Med. Chem., 2008, 51, 1577-1583.

29. S. A. Galal, K. H. Hegab, A. S. Kassab, M. L. Rodriguez, S. M. Kerwin, A. M. A. ElKhamry and H. I. El Diwani, Eur. J. Med. Chem., 2009, 44, 1500-1508.

30. M. J. Panzner, K. M. Hindi, B. D. Wright, J. B. Taylor, D. S. Han, W. J. Youngs and C. L. Cannon, Dalton Trans., 2009, 7308-7313.

31. B. F. Ruan, Y. P. Tian, H. P. Zhou, J. Y. Wu, Z. D. Liu, C. H. Zhu, J. X. Yang and H. L. Zhu, J. Organomet. Chem., 2009, 694, 2883-2887.

32. M. A. M. Abu-Youssef, V. Langer and L. Ohrstrom, Dalton Trans., 2006, 2542-2550.

33. M. A. M. Abu-Youssef, R. Dey, A. A. Massoud, Y. Gohar, V. Langer and L. Öhrström, Inorg. Chem., 2007, 46, 5893-5903.

34. M. A. M. Abu-Youssef, S. M. Soliman, V. Langer, Y. M. Gohar, A. A. Hasanen, M. A. Makhyoun, A. H. Zaky and L. R. Öhrström, Inorg. Chem., 2010, 49, 9788-9797.

35. J. Onuegbu, R. J. Butcher, C. Hosten, U. C. Udeochu and O. Bakare, Acta Cryst. E, 2007, 63, m2309-m2310.

36. M. McCann, B. Coyle, S. McKay, P. McCormack, K. Kavanagh, M. Devereux, V. McKee, P. Kinsella, R. O'Connor and M. Clynes, BioMetals, 2004, 17, 635-645.

37. F. H. Allen, Acta Cryst. B, 2002, 58, 380-388.

38. H. Y. Liu, H. Wu, J. F. Ma, S. Y. Song, J. Yang, Y. Y. Liu and Z. M. Su, Inorg. Chem., 2007, 46, 7299-7311. 
39. A. R. Biju and M. V. Rajasekharan, Polyhedron, 2008, 27, 2065-2068.

40. P. Kulkarni, S. Padhye and E. Sinn, Inorg. Chim. Acta, 2001, 321, 193-199.

41. H.-J. Yang, H.-Z. Kou, F. Gao, A.-L. Cui and R.-J. Wang, Acta Cryst. E, 2004, 60, m611m613.

42. S. Menon and M. V. Rajasekharan, Polyhedron, 1998, 17, 2463-2476.

43. P. Kulkarni, S. Padhye, E. Sinn, C. E. Anson and A. K. Powell, Inorg. Chim. Acta, 2002, 332, $167-175$.

44. Z.-Y. Wu and D.-J. Xu, Acta Cryst. E, 2004, 60, m839-m841.

45. R.-L. Zhang, J.-S. Zhao, S.-Y. Yang and S. W. Ng, Acta Cryst. E, 2004, 60, m262-m263.

46. R. L. Zhang, J. S. Zhao, Q. Z. Shi and S. W. Ng, Acta Cryst. E, 2003, 59, m476-m477.

47. N. C. Kasuga, R. Yamamoto, A. Hara, A. Amano and K. Nomiya, Inorg. Chim. Acta, 2006, 359, 4412-4416.

48. J.-A. Zhang, M. Pan, J.-Y. Zhang, H.-K. Zhang, Z.-J. Fan, B.-S. Kang and C.-Y. Su, Polyhedron, 2009, 28, 145-149.

49. A. Eshwika, B. Coyle, M. Devereux, M. McCann and K. Kavanagh, Biometals, 2004, 17, 415-422.

50. R. Lopez-Garzon, M. A. Romero-Molina, A. Navarrete-Guijosa, J. M. Lopez-Gonzalez, G. Alvarez-Cienfuegos and M. M. Herrador-Pino, J. Inorg. Biochem., 1990, 38, 139.

51. T. Yamane and N. Davidson, Biochim. Biophys. Acta, 1962, 55, 609-\&.

52. B. Nordén, Y. Matsuoka and T. Kurucsev, Biopolymers, 1986, 25, 1531-1545.

53. H. S. Rosenkranz and S. Rosenkranz, Antimicrob. Ag. Chemother., 1972, 22, 373-\&.

54. B. Nordén, M. Kubista and T. Kurucsev, Quart. Rev. Biophys., 1992, 25, 51-170. 